\title{
Perbedaan Kekuatan Geser Perlekatan (Shear Bond Strength) Antara Self-Adhering Flowable Composite dan Flowable Composite dengan Sistem Adhesif Self - Etch pada Dentin
}

\author{
Tanjung $\mathrm{S}^{1}$, Djuanda $\mathrm{R}^{1}$, Evelyna $\mathrm{A}^{1}$ \\ 1. Fakultas Kedokteran Gigi, Universitas Kristen Maranatha, Bandung, 40164, Indonesia \\ Email: steventanjung@yahoo.co.id
}

\begin{abstract}
Abstrak
Restorasi merupakan tindakan untuk mengembalikan struktur jaringan keras gigi yang telah hilang akibat karies. Flowable composite memiliki kemampuan adaptasi yang baik pada dinding kavitas sehingga banyak digunakan sebagai intermediate layer. Komposit membutuhkan sistem adhesif untuk berikatan secara kimiawi dengan jaringan keras gigi. Self - adhering flowable composite menggabungkan etsa, primer, dan adhesif dalam satu kemasan flowable. Penelitian ini dilakukan dengan tujuan untuk mengetahui perbedaan kekuatan geser pelekatan antara self - adhering flowable composite dan flowable composite dengan sistem adhesif self-etch pada dentin.

Jumlah sampel yang digunakan sebanyak 38 buah. Setelah dentin dipreparasi dan difiksasi, sampel dibagi menjadi dua kelompok, masing - masing kelompok terdiri dari 19 sampel. Kelompok 1 diaplikasikan self - adhering flowable composite, kelompok 2 diaplikasikan flowable composite dengan sistem adhesif self-etch. Sampel direndam dalam normal saline $\mathrm{pH}$ 6,8 dan disimpan selama 24 jam, kemudian dikeringkan dan diuji kekuatan geser pelekatan dengan menggunakan universal testing mechine. Data yang diperoleh dianalisis dengan uji $\mathrm{t}$ tidak berpasangan.

Hasil pengujian dengan uji $\mathrm{t}$ tidak berpasangan menunjukkan bahwa terdapat perbedaan kekuatan geser pelekatan yang signifikan antara kedua kelompok, $\mathrm{p}=0,000 \quad(\mathrm{p}<0,05)$. Kesimpulan penelitian ini adalah terdapat perbedaan kekuatan geser pelekatan yang signifikan antara self - adhering flowable composite dan flowable composite dengan sistem adhesif self - etch pada dentin.
\end{abstract}

Kata kunci: Kekuatan geser perlekatan, self - adhering flowable composite, flowable composite, dan sistem adhesif self-etch.

\begin{abstract}
Restoration is a treatment to restore the structure of missing dental hard tissue due to caries. Flowable composite has good adaptability to the cavity wall so that it is widely used as an intermediate layer. Composite resins require an adhesive system to bond chemically with dental hard tissue. Self - adhering flowable composite combining etching, priming, and adhesive in one flowable package. This study was conducted with the aim to
\end{abstract}


determine the difference in shear bond strength between Self - adhering flowable composite and flowable composite with self-etch adhesive system on dentine.

The number of samples used was 38 pieces. After dentin was prepared and fixed, samples was divided into 2 groups, each group consisting of 19 samples. First group was applied with self - adhering flowable composite, second group was applied with flowable composite with self-etch adhesive system. Samples was immersed in pH 6.8 normal saline and stored for 24 hours, then dried and shear bond strength was tested using a universal testing machine. The data obtained were analyzed using independent $t$-test.

The statistical analysis using independent $t$-test showed that there were significant differences in the shear bond strength between the two groups, $p=0,000(p<0.05)$. The study concluded that there is difference of shear bond strength between self - adhering flowable composite and flowable composite with self-etch adhesive system on dentine.

Keywords: Shear bond strength, Self - adhering flowable composite, flowable composite, and self-etch adhesive system.

\section{Pendahuluan}

Restorasi merupakan suatu tindakan untuk mencegah proses berkembangnya karies dan mengembalikan struktur jaringan keras gigi yang telah hilang akibat karies, tujuannya adalah untuk mengembalikan fungsi mastikasi, estetis, kesehatan, dan kenyamanan pasien. Kebutuhan bahan restorasi masa kini adalah jenis bahan restorasi yang memiliki penampilan sewarna dengan gigi dan dapat ditempatkan secara langsung ke dalam kavitas yang telah dipreparasi. Resin komposit mulai banyak digunakan dalam beberapa dekade terakhir dalam kedokteran gigi konservatif, sebagai bahan restorasi gigi anterior maupun posterior. $^{1,2}$

Flowable composit pertama kali diperkenalkan pada tahun 1996 sebagai formulasi resin komposit dengan daya alir yang tinggi. Flowable composite merupakan modifikasi resin komposit dengan komposisi bahan pengisi rendah yang berpengaruh pada rendahnya viskositas, kemampuan pembasahan yang tinggi pada permukaan, dan daya alir bahan yang tinggi, sehingga meningkatkan kemampuan adaptasi pada dasar dan dinding kavitas. Volume bahan pengisi pada flowable composite dikurangi tetapi tetap mempertahankan ukuran partikel yang sama seperti komposit hibrid konvensional. Ukuran partikel flowable composite adalah $0,7-3,0 \mu \mathrm{m}$ dengan volume $42-53 \%$ dan mengandung fluoride. ${ }^{3}$

Flowable composite banyak digunakan oleh para klinisi sebagai intermediate layer untuk menciptakan adaptasi yang baik pada dinding kavitas. Intermediate layer merupakan lapisan perantara yang digunakan untuk mencegah kebocoran mikro pada tepi restorasi. Kebocoran mikro pada restorasi resin komposit dapat disebabkan oleh adanya celah marginal yang terbentuk akibat dari resin komposit yang mengalami pengkerutan selama polimerisasi. $^{3-6}$

Flowable composite konvensional tidak mampu berikatan secara kimiawi dengan jaringan keras gigi sehingga dibutuhkan suatu sistem adhesif. Sistem adhesif merupakan suatu proses interaksi zat padat maupun cair dari suatu bahan adhesif dengan bahan lain (adherend). Penggunaan bahan adhesif di bidang kedokteran gigi dimulai pada tahun 1955 oleh Buonocore yang melaporkan penggunaan asam fosfor $85 \%$ untuk meningkatkan 
retensi resin akrilik pada enamel. Prinsip adhesi resin komposit pada dasarnya adalah keterpautan secara mikromekanik (mechanical interlocking), yaitu melalui resin tags yang dihasilkan oleh infiltrasi monomer resin pada mikroporositas dari permukaan enamel yang telah dietsa. Sistem adhesif dikembangkan lebih jauh yaitu ke permukaan dentin. Dentin memiliki kandungan air dan organik lebih tinggi dibandingkan enamel, hal ini menyebabkan dentin bersifat lembab, sehingga material adhesif harus bersifat hidrofilik untuk dapat berikatan baik dengan dentin. Resin komposit mempunyai sifat hidrofobik, sehingga komposisi sistem adhesif harus terdiri dari monomer resin hidrofobik dan hidrofilik. $^{7}$

Sistem adhesif kedokteran gigi telah berkembang menjadi beberapa generasi dengan perubahan pada struktur kimia, mekanisme ikatan, jumlah langkah aplikasi, teknik aplikasi, dan keefektifan klinis. Sistem adhesif one - step self - etch merupakan perkembangan generasi ke - tujuh dari sistem adhesif dengan tetap menggunakan kombinasi monomer resin hidrofobik dan hidrofilik, selain itu, nilai kekuatan ikatan pada dentin dalam kisaran yang dapat diterima secara klinis. Sistem adhesif one - step self - etch menggabungkan teknik etsa, pemberian monomer hidrofilik atau primer dan adhesif pada struktur gigi dalam satu tahap prosedur aplikasi. Sistem adhesif self-etch telah banyak menjadi pilihan dokter gigi karena relatif mudah penggunaannya dengan jumlah aplikasi yang sederhana dan waktu yang singkat serta dapat mengurangi sensitivitas post - operative karena menggunakan bahan etsa dengan konsentrasi rendah.,

Pada awal tahun 2010 diperkenalkan suatu kategori bahan restorasi komposit baru yaitu "self-adhering flowable composite" yang menggabungkan etsa, primer, dan adhesif dalam satu kemasan flowable. Sediaan bahan self - adhering flowable composite adalah Dyad Flow (Kerr). Self - adhering flowable composite dapat dipertimbangkan sebagai sistem adhesif generasi ke - delapan atau dapat mewakili persilangan antara sistem adhesif generasi ke - tujuh dan flowable composie. Kelebihan self-adhering flowable composite adalah aplikasi yang lebih cepat karena tanpa etsa dan bonding yang dilakukan secara terpisah. Self - adhering flowable composite juga mempunyai sifat yang pekat, sehingga dapat mempengaruhi perlekatan pada jaringan keras gigi.

Penelitian terdahulu memaparkan tentang perbedaan kekuatan geser perlekatan resin komposit packable dengan intermediate layer resin komposit flowable menggunakan bonding total - etch dan self - adhesive flowable terhadap dentin. Hasil penelitiannya menunjukan bahwa kekuatan geser perlekatan resin komposit packable dengan intermediate layer resin komposit flowable menggunakan bonding total - etch lebih besar dari self - adhesive flowable. Pada penelitian terdahulu disimpulkan bahwa terdapat perbedaan kekuatan geser yang bermakna pada kedua kelompok tersebut. ${ }^{5}$

Seiring dengan berkembangnya bahan - bahan dalam kedokteran gigi, maka hal tersebut perlu diikuti tindakan evaluasi terhadap bahan - bahan tersebut. Perlu diketahui bahwa bahan yang berbeda memiliki sifat yang berbeda. Beberapa objek memiliki sifat yang kuat dan keras, dan yang lainnya memiliki sifat lemah serta fleksibel. Uji kekuatan ikatan merupakan uji yang sering digunakan untuk menganalisa maupun mengevaluasi bahan - bahan kedokteran gigi, dan diantaranya adalah uji kekuatan geser perlekatan (Shear Bond Strength). ${ }^{1,5}$

Keberhasilan klinis dari flowable composite bergantung dari kemampuan bahan untuk berikatan dengan permukaan gigi, namun masih sedikit informasi yang tersedia mengenai 
kekuatan perlekatan self-adhering flowable composite. Sistem adhesif self-etch memiliki banyak keuntungan klinis, namun diperlukan penelitian tambahan untuk menentukan kemampuan pengetsaan dan ketahanan ikatan di dalam situasi klinis yang berbeda. Berdasarkan pemaparan di atas maka penulis tertarik ingin meneliti perbedaan kekuatan geser perlekatan antara self-adhering flowable composite dan flowable composite dengan bahan adhesif self-etch pada dentin. ${ }^{10}$

\section{Metode Penelitian}

Objek penelitian yang terdiri dari 38 gigi premolar permanen maksila yang telah diekstraksi dan dibersihkan. Permukaan gigi diberi garis penanda menggunakan spidol warna hitam setinggi $2 \mathrm{~mm}$ yang diukur dengan penggaris di atas Cemento Enamel Junction pada sisi mesial gigi untuk menandai kedalaman preparasi gigi. Masing - masing gigi difiksasi dengan cara menekan gigi ke dalam pipa PVC (diameter $2 \mathrm{~cm}$ dan tinggi 3 $\mathrm{cm})$ yang diisi dengan resin bening polyester dengan memperhatikan posisi garis penanda sejajar terhadap lantai. Setelah semua gigi difiksasi pada pipa PVC, mahkota gigi dipreparasi dengan memotong permukaan oklusal secara mendatar setinggi garis penanda untuk mendapatkan luas permukaan dentin dengan besar diameter minimal $3 \mathrm{~mm}$, menggunakan diamond bur yang terpasang pada handpiece high - speed. Permukaan dentin dihaluskan dengan Kertas Silikon Karbida nomor 600 di bawah air mengalir. Masing masing gigi dihaluskan sebanyak 25 kali gesekan dengan potongan kecil kertas Silikon Karbida untuk menghasilkan ketebalan smear layer yang seragam. Untuk mendapatkan bentuk dan ukuran tumpatan yang seragam, dilakukan pemasangan alat cetak komposit yang pada bagian tengah terdapat lubang berbentuk silinder dengan diameter $3 \mathrm{~mm}$ dan tinggi $2 \mathrm{~mm}$. Sampel dibagi secara acak menjadi 2 kelompok. ${ }^{5,7,11}$

Kelompok satu adalah 19 gigi yang diberi perlakuan dengan self-adhering flowable composite (Dyad Flow, Kerr). Permukaan dentin pada sampel kelompok 1 dibersihkan seluruhnya dengan semprotan air dan semprotan udara dengan tekanan maksimum selama 5 detik. Sebarkan Dyad Flow dari dispensing tip yang telah disediakan. Aplikasikan Dyad Flow dengan teknik brushing motion menggunakan brush khusus dengan tekanan sedang selama 20 detik untuk membentuk lining pada dentin dengan ketebalan kurang dari 0,5 mm. Lakukan penyinaran pada lapisan tersebut menggunakan light curing unit selama 20 detik. Setelah membentuk lining, aplikasikan lagi Dyad Flow dengan ketebalan $2 \mathrm{~mm}$. Kemudian dilakukan penyinaran menggunakan light curing unit selama 20 detik. Kelebihan komposit dibersihkan menggunakan ekskavator kecil dan pemolesan menggunakan polishing disc.

Kelompok dua adalah 19 gigi yang diberi perlakuan dengan flowable composite (Tetric N - Flow, Ivoclar Vivadent) dengan menggunakan bonding self - etch (Tetric $\mathrm{N}-$ Bond Universal, Ivoclar Vivadent). Permukaan dentin pada sampel pada kelompok 2 dibersihkan seluruhnya dengan semprotan air dan semprotan udara dengan tekanan maksimum selama 5 detik. Aplikasi selapis tipis Tetric N-Bond Universal dan dioleskan pada dentin menggunakan microbrush selama 20 detik, kemudian dikeringkan menggunakan semprotan udara sampai mendapatkan permukaan yang mengkilap. Kemudian dilakukan penyinaran menggunakan light curing unit selama 10 detik. Langkah selanjutnya aplikasikan Tetric $\mathrm{N}$ - Flow dengan ketebalan 2 mm. Kemudian dilakukan 
penyinaran menggunakan light curing unit selama 20 detik. Kelebihan komposit dibersihkan menggunakan ekskavator kecil dan pemolesan menggunakan polishing disc. Semua sampel kelompok 1 dan kelompok 2 direndam dalam wadah yang berisi larutan normal saline selama 24 jam. Hal ini dilakukan dengan tujuan untuk mensimulasi keadaan dalam rongga mulut.

Sampel diuji kekuatan geser perlekatannya dengan menggunakan Universal Testing Machine. Sampel dipasang pada cakram penggenggam, dengan posisi permukaan dentin yang telah ditumpat tegak lurus terhadap lantai. Kemudian posisikan batang penggeser dengan posisi knife chisel edge berada $1 \mathrm{~mm}$ di atas perlekatan resin komposit dengan permukaan dentin dan tegak lurus terhadap lantai. Mesin dihidupkan dengan kapasitas beban maksimum $5 \mathrm{kN}$ dan kecepatan $0,5 \mathrm{~mm} /$ menit sehingga batang penggeser tersebut akan bergerak menggeser resin komposit sampai terlepas dari permukaan dentin. Gaya geser akan tampil di layar monitor yang tersambung dengan Universal Testing Machine.

Analisis hasil penelitian diawali dengan uji normalitas untuk melihat apakah penyebaran data sampel berdistribusi normal atau tidak menggunakan uji Shapiro - Wilk karena jumlah sampel $\leq 50$. Dilakukan uji homogenitas Levene untuk menguji perbedaan varians antara kedua kelompok. Kemudian dilakukan uji hipotesis dengan menggunakan uji independent $t$ - test jika data berdistribusi normal. Hipotesis Statistik pada penelitian ini, $\mathrm{H}_{1}=$ Terdapat perbedaan kekuatan geser perlekatan antara self - adhering flowable composite dan flowable composite dengan bahan adhesif self - etch pada dentin. Ho = Tidak ada perbedaan kekuatan geser perlekatan antara self-adhering flowable composite dan flowable composite dengan bahan adhesif self - etch pada dentin.

\section{Hasil}

Pengukuran kekuatan geser perlekatan dilakukan dengan menggunakan Universal Testing Machine. Hasil pengukuran yang terlihat pada monitor Universal Testing Machine adalah besar gaya yang diperlukan untuk menggeser bahan restorasi hingga terlepas dari permukaan dentin dalam satuan Newton $(\mathrm{N})$. Luas permukaan dentin yang digunakan dalam penelitian yaitu sebesar: $\pi \times \mathrm{r}^{2}=3,14 \times 1,5^{2}=7,065 \mathrm{~mm}^{2}$. Hasil pengukuran kekuatan geser perlekatan antara self - adhering flowable composite (Kelompok 1) dan flowable composite dengan bahan adhesif self - etch pada dentin (Kelompok 2) ditampilkan pada Tabel 4.1 .

Tabel 4. 1. Hasil Uji Kekuatan Geser Perlekatan.

\begin{tabular}{ccc}
\hline Sampel & \multicolumn{1}{c}{ Kekuatan Geser Perlekatan (MPa) } \\
\hline & Kelompok 1 & Kelompok 2 \\
\hline 1 & 5,8812 & 15,5289 \\
3 & 8,1713 & 16,0920 \\
\hline
\end{tabular}




\begin{tabular}{ccc}
\hline Sampel & \multicolumn{2}{c}{ Kekuatan Geser Perlekatan (MPa) } \\
\hline 4 & Kelompok $\mathbf{~}$ & Kelompok 2 \\
5 & 5,0042 & 15,0729 \\
6 & 6,9674 & 16,4034 \\
7 & 4,4243 & 15,3352 \\
8 & 4,4177 & 16,1953 \\
9 & 5,7558 & 14,7573 \\
10 & 5,0157 & 14,8968 \\
11 & 6,4991 & 14,2017 \\
12 & 6,9285 & 13,6771 \\
13 & 4,7939 & 18,1415 \\
14 & 6,4294 & 15,6051 \\
15 & 5,0092 & 15,0559 \\
16 & 8,0215 & 16,8054 \\
17 & 5,9888 & 13,8205 \\
18 & 6,9172 & 15,4890 \\
19 & 8,2995 & 14,3857 \\
\hline Rerata & 6,4855 & 15,4777 \\
\hline
\end{tabular}

Berdasarkan data yang ditampilkan pada tabel 4.1., diperoleh nilai rerata kekuatan geser perlekatan pada kelompok 2 dengan perlakuan menggunakan flowable composite Tetric N - Flow (Ivoclar Vivadent) dengan bahan adhesif Tetric N - Bond Universal (Ivoclar Vivadent) sebesar 15,4275 MPa dan nilai rerata kelompok 1 yang diberi perlakuan menggunakan self-adhering flowable compoite Dyad Flow (Kerr) sebesar 6,2264 MPa.

Untuk mengetahui normal atau tidaknya distribusi data, dan perbedaan varians antara kedua kelompok, dilakukan uji normalitas Sapiro - Wilk dan uji homogenitas Levene. Hasil uji normalitas distribusi data dan uji homogenitas ditampilkan pada tabel 4.2. dan tabel 4.3.

Tabel 4. 2. Hasil Uji Normalitas Sapiro - Wilk.

\begin{tabular}{cccc}
\hline Kelompok & \multicolumn{3}{c}{ Shapiro-Wilk } \\
\hline & Statistik & $\mathrm{df}$ & $p$ \\
2 & 0,944 & 19 & 0,314 \\
& 0,967 & 19 & 0,712 \\
\hline
\end{tabular}

Tabel 4. 3. Hasil Uji Homogenitas Levene.

\begin{tabular}{cccc}
\hline Levene Statistic & df1 & df2 & $\boldsymbol{p}$ \\
\hline 1,024 & 1 & 36 & 0,318 \\
\hline
\end{tabular}

Berdasarkan data yang telah ditampilkan pada table 4.2., didapatkan hasil uji normalitas masing - masing kelompok dengan nilai $p>0,05$, maka disimpulkan bahwa 
data sampel berdistribusi normal. Dari hasil uji homogenistas diketahui nilai $p>0,05$ maka disimpulkan bahwa data sampel berasal dari populasi yang memiliki varians yang sama (homogen).

Untuk menentukan apakah perbandingan rerata kekuatan geser perlekatan antara self adhering flowable composite dan flowable composite dengan bahan adhesif self - etch bermakna secara statistik, maka dilakukan uji independent $t$-test. Hasil pengolahan data ditampilkan pada tabel 4.4.

Tabel 4. 4. Hasil Perhitungan Statistik Menggunakan Uji Independent $t$-Test.

\begin{tabular}{|c|c|c|c|c|c|c|}
\hline \multicolumn{7}{|c|}{ t-test for Equality of Means } \\
\hline \multirow[t]{2}{*}{$\mathrm{t}$} & \multirow[t]{2}{*}{ df } & \multirow[t]{2}{*}{$\begin{array}{c}p \\
\text { (2-tailed) }\end{array}$} & \multirow[t]{2}{*}{$\begin{array}{c}\text { Mean } \\
\text { Difference }\end{array}$} & \multirow[t]{2}{*}{$\begin{array}{l}\text { Std. Error } \\
\text { Difference }\end{array}$} & \multicolumn{2}{|c|}{$\begin{array}{l}\text { 95\% Confidence } \\
\text { Interval of the } \\
\text { Difference }\end{array}$} \\
\hline & & & & & Lower & Upper \\
\hline$-24,396$ & 36 & 0,000 & $-9,20116$ & 0,37715 & $-9,96606$ & $-8,43626$ \\
\hline
\end{tabular}

Berdasarkan hasil uji independent $t$ - test yang ditampilkan pada tabel 4.3., didapatkan nilai signifikansi 0,000 yang berarti hasil analisis statistik independent $t$ - test menunjukkan adanya perbedaan kekuatan geser perlekatan yang bermakna antara kelompok 1 dan kelompok $2(p<0,05)$, sehingga dengan demikian Ho ditolak dan $\mathrm{H}_{1}$ diterima.

\section{Diskusi}

Hasil penelitian menunjukkan bahwa terdapat perbedaan kekuatan geser perlekatan yang signifikan antara self - adhering flowable composite dan flowable composite dengan bahan adhesif self - etch pada dentin. Kekuatan geser perlekatan pada kelompok flowable composite Tetric $\mathrm{N}$ - Flow dengan bahan adhesif Tetric $\mathrm{N}$ - Bond Universal sebesar 15,4275 MPa, lebih besar dibandingkan dengan kekuatan geser perlekatan kelompok yang diberi perlakuan self-adhering flowable compoite Dyad Flow sebesar 6,2264 MPa.

Faktor penting dalam keberhasilan klinis restorasi resin komposit adalah terbentuknya pelekatan bonding yang kuat antara resin komposit dan jaringan keras gigi. Faktor yang dapat mempengaruhi kemampuan bonding dari sistem adhesif pada dentin yaitu kemampuan pembasahan (wettability), kepekatan bahan (viscosity), kapasitas ikatan kimia, adaptasi antara adherend dan bahan adhesif yang rapat dan komposisi kimia dari sistem adhesif termasuk solvent. ${ }^{5,10}$

Dyad Flow mengandung komponen monomer mengandung glycerol phosphate dimethacrylate (GPDM), hydroxyethyl methacrylate (HEMA), bis - GMA dan juga menagndung 4 jenis bahan pengisi organik yaitu prepolymerized filler, barium glass $1 \mu \mathrm{m}$, nano - sized colloidal silica, nano - sized ytterbium fluoride. Tetric N - Bond Universal mengandung komposisi monomer hidrofilik HEMA, monomer hidrofobik decandioldimethacrylate (D3MA), dan monomer intermediasi bis - GMA. Kombinasi 
monomer tersebut memungkinkan Tetric $\mathrm{N}$ Bond Universal untuk secara andal menjembatani celah antara substrat gigi yang bersifat hidrofilik dan resin yang bersifat hidrofobik, dalam segala kondisi permukaan. Tetric $\mathrm{N}$ - Bond Universal juga mengandung monomer 10 - MDP, MCAP, solvent hidrofilik etanol dan air., ${ }^{8,13}$

Perbedaan kekuatan geser perlekatan kemungkinan disebabkan karena adanya perbedaan tingkat viskositas dari Dyad Flow dengan Tetric N Bond Universal. Rahmawati pada tahun 2013 mengungkapkan bahwa agar bahan bonding dan resin komposit mendapatkan perlekatan yang baik dengan dentin maka bahan tersebut harus memberikan pembasahan (wettability) yang baik pada permukaan gigi, mempunyai tingkat viskositas yang tepat agar dapat mengalir pada permukaan yang akan dilakukan aplikasi bahan bonding, dan memiliki ketebalan lapisan bahan bonding yang cukup. Dyad Flow memiliki tingkat viskositas yang lebih tinggi dari bahan adhesif Tetric $\mathrm{N}$ Bond Universal karena jumlah bahan pengisinya. Jumlah bahan pengisi yang lebih tinggi akan meningkatkan viskositas bahan. Bahan dengan viskositas yang lebih tinggi membentuk sudut kontak yang yang lebih besar dibandingkan dengan bahan yang memiliki viskositas rendah. Sudut kontak yang besar dapat menyebabkan bahan bonding tidak mudah mengalir ke dalam mikroporositas sehingga daya penetrasi bahan terhadap permukaan gigi menjadi kurang baik, sedangkan sudut kontak yang kecil dapat mengakibatkan bahan bonding menyebar ke permukaan gigi sehingga mampu membasahi permukaan gigi dengan baik. Pembasahan permukaan yang baik menyebabkan adaptasi pada permukaan gigi yang baik. Adaptasi permukaan yang baik sangat diperlukan untuk meningkatkan kekuatan perlekatan bahan bonding. ${ }^{1,10}$

Perbedaan kekuatan geser perlekatan Dyad Flow dengan Tetric N Bond Universal dapat pula dipengaruhi oleh mekanisme ikatan kimia antara monomer fungsional dengan substrat dentin. Produsen menyatakan bahwa mekanisme ikatan Dyad Flow terhadap dentin melalui ikatan kimia antara monomer fosfat glycerol phosphate dimethacrylate (GPDM) dengan ion kalsium gigi. Poitevin pada tahun 2013 menjelaskan bahwa monomer GPDM yang digunakan pada Dyad Flow lebih berperan sebagai perekat daripada menyebabkan ikatan kimiawi dengan struktur gigi, sedangkan self - adhering flowable composite sebaiknya mengandung komposisi monomer fungsional yang memiliki potensi ikatan kimia yang efektif agar dapat berpenetrasi dengan baik. ${ }^{8}$

Tetric N Bond Universal mengandung monomer 10 - methacryloyloxydecyl dihydrogenphosphate (10 - MDP). Monomer 10 - MDP adalah monomer amfifilik fungsional serbaguna dengan gugus metakrilat hidrofobik pada satu sisi yang mampu berikatan kimia dengan restorasi, dan gugus hidrofilik polar fosfat pada sisi lain yang mampu berikatan secara kimia ke jaringan gigi. Rantai karbon panjang dari monomer menjadikannya cukup hidrofobik. Monomer 10 - MDP adalah monomer yang paling hidrofobik dari semua monomer fungsional yang biasanya digunakan dalam adhesif dental dengan koefisien partisi 4,1 (koefisien partisi pada dasarnya adalah ukuran seberapa hidrofilik atau hidrofobik suatu bahan kimia). Sifatnya yang hidrofobik penting dalam hal daya tahan, karena penyerapan air dan ketidakstabilan hidrolitik dari antarmuka adhesif dari waktu ke waktu merupakan salah satu penyebab utama kegagalan ikatan. Sifat hidrofobik juga membuat 10 - MDP relatif stabil dalam larutan, yang penting dalam hal ketahanan dalam jangka waktu lama. 10 - MDP juga merupakan salah satu dari beberapa monomer yang digunakan dalam adhesif kedokteran gigi yang telah terbukti benar - benar berikatan 
secara kimia dengan jaringan gigi melalui ikatan ionik dengan kalsium yang ditemukan dalam hidroksiapatit. Garam kalsium - MDP yang stabil terbentuk selama reaksi ini dan disimpan dalam lapisan nano yang terbentuk dengan sendirinya. Jenis interaksi molekuler ditambah dengan sifat relatif hidrofobik dari 10 - MDP terpolimerisasi dapat menjelaskan mengapa Tetric N Bond Universal sangat efektif dalam menciptakan antarmuka adhesif yang lebih baik dari Dyad Flow. ${ }^{14}$

Faktor lain yang dapat mempengaruhi kemampuan bonding dari sistem adhesif pada dentin yaitu komposisi kimia dari sistem adhesif termasuk solvent. El Zeiny pada tahun 2016 menyatakan bahwa solvent merupakan komponen yang penting untuk meningkatkan pembasahan gigi, meningkatkan penetrasi dari monomer fungsional, dan menyebabkan ikatan kimia yang lebih baik antara bahan adhesif dengan hidroksiapatit dentin, sehingga meningkatkan kekuatan perlekatan.. Tetric $\mathrm{N}$ Bond Universal terdiri dari monomer hidrofilik, monomer hidrofobik yang terlarut dalam air dan solvent organik etanol. Monomer dapat menembus smear layer dan melakukan demineralisasi ringan pada dentin dibawahnya, membentuk ikatan dengan kolagen dentin dan ikatan ionik dengan hidroksiapatit. Kandungan solvent yang tinggi, khususnya air, diperlukan untuk ionisasi monomer asam yang memadai., ${ }^{8,15}$

Hasil penelitian yang dilakukan oleh Koliniotou pada tahun 2014 dengan judul "Shear bond strength of a solvent - free adhesive versus contemporary adhesive systems" menunjukkan bahwa sistem adhesif self - etch Bond 1 SF mengandung monomer 4 - MET, yang terbukti dapat membentuk ikatan ionik dengan hidroksiapatit, tetapi dengan ketiadaan solvent pada bahan adhesif ini menyebabkan lapisan hibrid yang terbentuk hanya sebagian dan terdapat celah antara bahan dengan substrat dentin sehingga dapat mengurangi kekuatan perlekatan terhadap dentin. Berdasarkan penelitian El - Zeiny pada tahun 2016 yang menyatakan bahwa "meskipun self - adhering flowable composite mengandung HEMA untuk meningkatkan kemampuan pembasahan, komposit ini tidak mengandung solvent", dapat ditarik kesimpulan bahwa ketiadaan solvent pada pada komposisi Dyad Flow dapat menurunkan kekuatan perlekatan. ${ }^{8,15}$

\section{Kesimpulan}

Bedasarkan hasil penelitian dan analisis data, dapat ditarik kesimpulan bahwa terdapat perbedaan kekuatan geser perlekatan antara self - adhering flowable composite dan flowable composite dengan bahan adhesif self-etch pada dentin.

\section{Referensi}

1. Rahmawati D, Wijayanti N. The differences of tensile strength resin composite restorations on dentin with total etch system and self-adhesive flowable composite. $\mathbf{J}$ Ked Gi. 2014;17(4):1-7.

2. Susra W, Nur DL, Puspita, S. Perbedaan kekuatan geser dan kekuatan tarik pada restorasi resin komposit microhybrid dengan bonding generasi $\mathrm{v}$ dan bonding generasi vii. Indones Dent J. 2013;2(2):68-75. 
3. Dahniar A, Santosa P, Darajati S. Perbedaan kebocoran mikro restorasi resin komposit packable menggunakan bonding total etch, self etch dan self adhesive. J Ked Gi. 2014;5(2):21-28.

4. Maika R, Noor H, Widyastuti J. Perbandingan kekuatan tarik resin komposit nanofill pada kavitas kelas $\mathrm{v}$ dengan bahan adhesif self-etch dan total-etch. Nask Publ Fak Ked Gi UMS. Surakarta: 2015.

5. Diana S, Santosa P, Daradjati S. Perbedaan kekuatan geser pelekatan resin komposit packable dengan intermediate layer resin komposit flowable menggunakan bonding total-etch dan self adhesive flowable terhadap dentin. J Ked Gi. 2014;5(2):209-218.

6. Garcia RN, Morelli AE, da Silva BS, Giongo BM, Largura GS, Mensch LF, et al. Bonding performance of a self-adhering flowable composite to substrates used in direct technique. RSBO. 2013;10(4):343-349.

7. Puspitasari D. Perbandingan kuat rekat resin komposit pada dentin dengan sistem adhesif self etch 1 tahap (one step) dan 2 tahap (two step). Dent J Ked Gi. 2014;II(1):89-94.

8. El-Zeiny HM, El-Fattah WM, Abd-Elmotie MA. Shear bond strength of self adhering flowable composites after preliminary. Alex Dent J. 2016; 41:318-322

9. Vichi A, Goracci C, Ferrari M. Clinical study of the self-adhering flowable composite resin vertise flow in class i restorations: six-month follow-up. Int Dent Sa. 2011;12(1):14-23.

10. Tuloglu N, Tunc ES, Ozer S, Bayrak S. Shear bond strength of self-adhering flowable composite on dentin with and without application of an adhesive system. $\mathbf{J}$ Appl Biomater Funct Mater. 2014;12(2):97-101.

11. Iftekhar $\mathrm{H}$. Comparative evaluation of shear bond strength of three different generations of adhesive to dentin: an in vitro study. Res Rev A J Dent. 2014;5(2):917.

12. Attin R, Stawarczyk B, Keçik D, Knösel M, Wiechmann D. Shear bond strength of brackets to demineralize enamel after different pretreatment methods. Angle Orthod. 2012;82(1):56-61.

13. Siqueira FSF, Cardenas AM, Ocampo JB, Hass V, Bandeca MC, Gomes JC, et al. Bonding performance of universal adhesives to eroded dentin. J Adhes Dent. 2018;20(2):121-132.

14. Alex G. Universal adhesives: the next evolution in adhesive dentistry. Compend Contin Educ Dent. 2015;36(1):15-26.

15. Koumpia EK, Kouros P, Antoniades MH. Shear bond strength of a "solvent-free" adhesive versus contemporary adhesive systems. Braz J Oral Sci. 2014;13(1):64-69. 